\title{
Evaluation of estrogenic disrupting potency in aquatic environments and urban wastewaters : combination of chemical and biological analysis
}

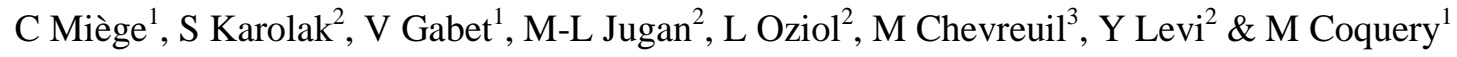 \\ 1 : Cemagref, UR QELY, 3 bis quai Chauveau, CP 220 - 69336 Lyon cedex 09, France \\ 2: Univ. Paris Sud 11, IFR 141, Faculté de Pharmacie, Laboratoire Santé Publique - Environnement, 5 rue J.B. \\ Clément, 92290 Chatenay-Malabry, France \\ 3 : Laboratoire Hydrologie et Environnement - EPHE, UMR 7619, 4, place Jussieu 75252 Paris cedex 05, \\ France
}

Corresponding authors : cecile.miege@cemagref.fr, sara.karolak@u-psud.fr

\begin{abstract}
Estrogenic disrupting potency was studied in rivers and wastewaters in the Orge catchment near Paris area, using analytical and biological approaches simultaneously. The MELN test was applied to surface water samples, urban storm runoff and WWTP effluent in parallel to analytical determinations of natural estrogens and synthetic estrogen (ethinylestradiol) using liquid chromatography and tandem mass spectrometry. Estrone was quantified in all samples, from 0.1 to $15.7 \mathrm{ng} \cdot \mathrm{L}^{-1}$. $\beta$-Estradiol was also quantified in all samples, but at a lower level: from 0.1 to $2.3 \mathrm{ng} \cdot \mathrm{L}^{-1}$. $\alpha$-Estradiol was never detected. Ethinylestradiol was only quantified in WWTP effluent $\left(0.2 \mathrm{ng} \cdot \mathrm{L}^{-1}\right)$; Estriol was measured in WWTP effluent $\left(12.1 \mathrm{ng} \cdot \mathrm{L}^{-1}\right)$ and downstream effluent $\left(4.9 \mathrm{ng} \cdot \mathrm{L}^{-1}\right)$. The biological responses using the MELN test closely followed the chemical ones. Analytical quantification of estrogens appears to be a simple way to trace estrogenic disruption in surface waters of urban areas as these hormones are the main responsible of effects.
\end{abstract}

Keywords: estrogenic hormones, chemical analysis, MELN tests, surface waters, urban wastewaters

\section{Introduction}

Natural estrogens are a group of steroid hormones including the main active hormone, 17ßestradiol, and estrone and estriol. Endocrine disruptors are defined as substances that interfere with the endocrine system and disrupt the physiological functions of hormones. The presence of estrogenic compounds in surface waters has been noted since the early 80s [1]. Numerous endocrine disruptors substances, such as industrial or domestic chemicals (plasticizers, flame retardants, pesticides...) and natural or synthetic hormones excreted by human bodies, reach the aquatic environment daily via sewage systems. Indeed, industrial and domestic wastewaters are recognised as the main sources for these pollutants which may act with 
different modes of disruption on the animal and human endocrine systems. The consequences of the presence of these substances in the aquatic environment are still largely unknown, but some negative impacts have been reported, for instance the feminization of fish in large rivers and toxicological effects on wildlife [2,3]. Thus, large scientific efforts are in progress to better evaluate the presence and the effect of these compounds in the environment and to identify their sources and modes of transfer to the aquatic ecosystems.

Many papers reported the presence of estrogenic hormones (i.e., estrone [E1], 17 $\beta$ and $\alpha-$ estradiol [17 $\beta$ and $\alpha$-E2], 17 $\alpha$-ethinylestradiol [EE2] and estriol [E3]) in wastewaters and surface waters. In a recent paper, Miège et al. [4] compiled concentrations measured in the dissolved phase of influents and effluents of wastewater treatment plants (WWTPs) with activated sludge processes, as well as removal efficiencies. Detailed dataset were drawn from 117 research papers covering a period from January 1997 to June 2006 for international studies and to February 2007 for French studies. In Table 1, we reported mean, minimum and maximum concentrations in WWTP influent and effluent for the 5 estrogenic hormones as well as their removals (data from [4]). Concentrations range from $0.4 \mathrm{ng} \cdot \mathrm{L}^{-1}$ for EE2 to 670 $\mathrm{ng} \cdot \mathrm{L}^{-1}$ for $\mathrm{E} 1$ in influents and from $0.1 \mathrm{ng} \cdot \mathrm{L}^{-1}$ for $\alpha-\mathrm{E} 2$ to $275 \mathrm{ng} \cdot \mathrm{L}^{-1}$ for $\mathrm{E} 3$ in effluents. Removals efficiencies range from $68 \%$ for EE2 to $92 \%$ for E3.Thus, although removal rates are relatively high, WWTPs represent nonetheless an evident source of estrogenic hormones contamination for surface waters. In France, some studies reported the concentration of estrogenic hormones in river water: Cargouët et al. [5] found concentrations of free E1, $\beta$-E2, E3 and EE2 in the dissolved phase between 1.0 and $3.2 \mathrm{ng} \cdot \mathrm{L}^{-1}$; Labadie et al. [6] analysed free and conjugated fractions of the same hormones in the dissolved and suspended particular phase of the Jalles d'Eysine river and detected none of them. In the dissolved phase of German rivers, Zuehlke et al. [7] analysed the free fraction of E1, $\beta$-E2 and EE2 in the Berlin area and detected only E1 in the range of $0.16-0.86 \mathrm{ng} \cdot \mathrm{L}^{-1}(\mathrm{n}=5)$; Ternes [8] did not quantify any of the studied estrogenic hormones $(\mathrm{E} 1, \beta-\mathrm{E} 2, \mathrm{EE} 2, \mathrm{n}=15)$. In the dissolved phase of German rivers and creeks, Kuch et al. [9] quantified E1 in 29 samples over 31, at an average concentration of $0.7 \mathrm{ng} \cdot \mathrm{L}^{-1}$; EE2 and $\beta$-E2 were quantified in about half of the samples, at an average concentration of 0.8 and $0.6 \mathrm{ng} \cdot \mathrm{L}^{-1}$, respectively; $\alpha$-E2 was quantified in 8 samples over 31 at an average concentration of $0.6 \mathrm{ng} \cdot \mathrm{L}^{-1}$. Beck et al. [10] measured the concentration of estrogenic hormones in the dissolved phase of 10 Baltic Sea sites and pointed out that E1 was always quantified in the range of $0.10-0.53 \mathrm{ng} \cdot \mathrm{L}^{-1} ; \beta$-E2 and E3 were never detected; and EE2 was quantified in all the sampling sites except one, between 0.45 and $17.2 \mathrm{ng} \cdot \mathrm{L}^{-1}$. In 
the dissolved phase of Italian rivers, Lagana et al. [11] found the free fraction of E1, $\beta$-E2, E3 and EE2 at respectively 8, 4, 1 and $3 \mathrm{ng} \cdot \mathrm{L}^{-1}$ (7 samples in the Tiber river), while Zuccato et al. [12], who analysed only EE2 did not quantify it (one sample in the Lambro river and 7 samples in the Po river). Other studies were realised all over the world: Boyd et al. [13] did not quantify E1 nor $\beta$-E2 in the dissolved phase of American rivers and lakes; Farré et al. [14] did not quantify E1, $\beta$-E2, E3, nor EE2 in the dissolved phase of Spanish rivers (3 sites); Morteani et al. [15] studied 19 sites of rivers and creek waters in Czech Republic and found $\mathrm{E} 1$ at $7.4 \mathrm{ng} \cdot \mathrm{L}^{-1}$ and $\mathrm{E} 3$ at $1.7 \mathrm{ng} \cdot \mathrm{L}^{-1}$ only at one site, $\beta$-E2 was detected at 7 sites at a maximum concentration of $3.8 \mathrm{ng} \cdot \mathrm{L}^{-1}$ and EE2 was detected at 6 sites at a maximum level of $4.6 \mathrm{ng} \cdot \mathrm{L}^{-1}$. In summary, most studies report concentrations of free estrogens in the dissolved phase and estrogens were not systematically detected in surface waters. Concentrations measured were generally in the range of $1 \mathrm{ng} \cdot \mathrm{L}^{-1}$ and rarely over $10 \mathrm{ng} \cdot \mathrm{L}^{-1}$. Since these molecules are moderately hydrophobic, with log Kow values between 2.6 for estriol and 4.1 for $17 \alpha$-ethinylestradiol, they have also been detected in sediments in few studies. For example, Labadie et al. [16] analysed 7 samples of river sediments from the River Ouse (UK) supposed to be differently contaminated (located from $200 \mathrm{~m}$ to $5 \mathrm{~km}$ downstream WWTP effluents). Measured concentrations varied between 0.4 and $3.3 \mathrm{ng} \cdot \mathrm{g}^{-1}$ dry weight for E1, $<0.03$ and $1.2 \mathrm{ng} \cdot \mathrm{g}^{-1}$ dry weight for E2 and were below $0.04 \mathrm{ng} \cdot \mathrm{g}^{-1}$ dry weight for EE2.

Chemical analyses of estrogenic hormones have the advantage to reach very low detection limits (in the range of sub-ng. $\mathrm{L}^{-1}$ ) and to precisely identify molecules. But other estrogenic disruptors are known to induce estrogenic effect in aquatic environments, such as bisphenol A, polybrominated diphenyl ethers, phthalates, organochlorines, alkylphenols or dioxin. They would have to be measured specifically as well. Hence, in order to check if estrogenic hormones are good tracers of urban sources of contamination of endocrine disruptors in aquatic environments, it appears valuable to combine chemical analysis of estrogenic hormones with biological tests of estrogenic effect.

Estrogenic activity can be measured using different biological tests. Global biological disrupting effects are generally expressed as equivalent estrogenic quantity of $17 \beta$-estradiol or EEQ. The YES-test based on recombinant yeast cultures expressing human estrogen receptor has been used for investigations in influents and effluents of WWTPs [17-19] and surface waters [20]. Levels were up to $130 \mathrm{ng} \cdot \mathrm{L}^{-1}$ EEQ in WWTPs influents, less than $20 \mathrm{ng} \cdot \mathrm{L}^{-1}$ EEQ in effluents and around $1 \mathrm{ng} \cdot \mathrm{L}^{-1}$ EEQ in surface waters. Korner et al. [21] used the E-screen 
test involving breast cancer human cells MCF-7 proliferation under estrogenic control to quantify estrogenic activity in WWTP influent and found concentrations between 58 and 70 ng. $\mathrm{L}^{-1}$ EEQ. The ER-CALUX and MELN tests are similar bioassays using respectively T47D and MCF-7 human breast cancer cells stably transfected with luciferase reporter gene. Murk et al. [22] used the ER-CALUX bioassay and quantified estrogenic agonist activities on estrogen receptors in influents (1.1 to $\left.119.8 \mathrm{ng} \cdot \mathrm{L}^{-1} \mathrm{EEQ}\right)$, effluents (0.03 to $\left.16.1 \mathrm{ng} \cdot \mathrm{L}^{-1} \mathrm{EEQ}\right)$ and surface waters (0.25 to $1.72 \mathrm{ng} \cdot \mathrm{L}^{-1}$ EEQ). Using the MELN test, Pillon et al. [23] found $1.4 \mathrm{ng} \cdot \mathrm{L}^{-1}$ EEQ in surface waters. In one of our previous study around the Paris great suburb area, Cargouët et al. [5] applied the MELN test and found 43 to $63 \mathrm{ng} \cdot \mathrm{L}^{-1}$ EEQ in influents, 2 to $24 \mathrm{ng} \cdot \mathrm{L}^{-1}$ EEQ in effluent and 1 to $3.2 \mathrm{ng} \cdot \mathrm{L}^{-1}$ EEQ in surface water. Thus, the estrogenic activities determined in areas located in different countries appeared relatively homogeneous. High levels are reported at the entry of WWTPs, then estrogenic activities are significantly reduced by the WWTPs, from 60 to $95 \%$, leading to residual EEQ values in surface water near 1-4 ng. $\mathrm{L}^{-1}$. However, the results may differ depending on the bioassay used. Thus, Nelson et al. [17] compared EEQ values obtained with the E-screen and the YES tests and obtained correlation factors between 0.56 and 0.75 , depending on the operating conditions. The sensitivity of the bioassay is expressed as the EC50 determined with 17 $\beta$-estradiol. The YES test appears less efficient, with an EC50 value of $203 \pm 67 \mathrm{pM}\left(55.3 \pm 18.3 \mathrm{ng} \cdot \mathrm{L}^{-1}\right)$, which is four times higher than the one measured using the E-screen test, i.e., $53.2 \pm 7.2 \mathrm{pM}$ $\left(14.5 \pm 2.0 \mathrm{ng} \cdot \mathrm{L}^{-1}\right)$ [17]. Sonneveld et al. [24] determined an EC50 value of $16 \mathrm{pM}\left(4.36 \mathrm{ng} \cdot \mathrm{L}^{-}\right.$ ${ }^{1}$ ) using the ER-CALUX test. This value is similar to the one calculated for the MELN test by Pillon et al. [23], i.e., $16.6 \mathrm{pM}\left(4.52 \mathrm{ng} \cdot \mathrm{L}^{-1}\right)$. Using the MELN test, Berckmans et al. [25] reported an average value two times higher than that reported by Pillon et al. [23], (i.e., $33 \pm 7$ $\mathrm{pM}$ or $8.99 \pm 1.91 \mathrm{ng} \cdot \mathrm{L}^{-1}$ ). This last difference underlines the importance of the variability inherent to biological material and to the operating conditions, such as the incubation time or the method for luciferase activity measurement. These factors should be assessed to optimize the sensitivity and the limit of detection of a bioassay. The MELN test was adapted in our laboratory and an EC50 value of $6.2 \pm 0.4 \mathrm{pM}\left(1.69 \pm 0.11 \mathrm{ng} \cdot \mathrm{L}^{-1}\right)$ was validated on several assays. It is worth to note that the MELN and ER-CALUX tests have been selected to define a standardized test for the in vitro evaluation of estrogenic activity [26]. In these studies, biological tests were used as a global approach to give an indication of the endocrine disruption risk for the aquatic wildlife exposed in the studied environments. 
As mentioned before, several substances are known to be estrogenic disruptors. These substances are able to react with estrogen receptor and, using this ability, could be detected with the previously described bioassays. However, their affinities to estrogen receptors are far weaker than the ones of natural estrogenic hormones or ethinylestradiol. For example, Pillon et al. [23] measured EC50 values with the MELN test of $339 \mathrm{pM}\left(74.70 \mathrm{ng} \cdot \mathrm{L}^{-1}\right)$ for $\mathrm{p}$ nonylphenol and $11 \mu \mathrm{M}\left(2.42 \mathrm{mg} \cdot \mathrm{L}^{-1}\right)$ for $\mathrm{n}$-nonylphenol. It appears interesting to compare biological results of estrogenic activity to analytical determinations of estrogenic substances, in particular for natural and synthetic estrogenic hormones. Such a study has already been realized by Cargouët et al. [5] on four WWTPs located upstream or downstream Paris (France) and surface waters. Estrogenic activities assessed by the MELN test were mainly associated to estrogenic hormone concentrations (E1, E2, E3 and EE2) quantified in WWTP influent and effluent samples. Using ponderation factors, chemical EEQ was estimated from estrogenic hormone concentrations and compared to biological EEQ: the chemical EEQ represented half of the biological EEQ in WWTP influent and were equal to the biological EEQ in effluent; the chemical EEQ were higher than the biological ones in surface water samples and this difference was partly explained by the relative high EE2 concentrations in comparison to WWTP samples. A similar study on wastewaters was developed by Nelson et al. [17] who found correlations factor (r) between 0.71 and 0.80 when comparing biological EEQ measured with the E-Screen or YES tests and chemical EEQ obtained from analytical determinations ( $\mathrm{n}=10$, effluent or influent from 5 WWTPs). In this study, the authors obtained chemical EEQ using estrogen equivalent factors reported in the literature for the different bioassays. Similarly, Salste et al. [18], using the YES test, showed that the main estrogenic activity observed in the effluents of one Finland WWTP was mainly due to E1.

The objective of our study was to assess estrogenic activity using the MELN tests for surface water samples, urban storm runoff and WWTP effluent, in parallel to analytical determination of natural estrogenic hormones and a synthetic one (i.e., ethinylestradiol). We chose to analyse surface water samples collected in different areas on a single catchment basin, with the aim of following the variation of estrogenic hormone concentration and biological activity along the river flow and urban and country planning. An urban storm runoff and a WWTP are located along the studied rivers, leading to an local input of ethinylestradiol and natural estrogenic hormones.

\section{Methods}




\subsection{Sampling sites and protocols}

Sampling was performed on the Orge river, an affluent of the Seine river. Its confluence is located in an urban area upstream Paris (figure 1). The Orge watershed has a surface of 952 $\mathrm{km}^{2}$; it is covered by agricultural lands upstream and is entirely urbanized downstream. The Orge river, contrary to its two main affluents (the Yvette and Remarde rivers) does not receive any WWTP input. However, some diffuse domestic wastewater discharges can reach the Orge river due to poor connections on the stormwater sewer system. Sampling sites were chosen upstream or downstream of specific points (i.e., urban sites, WWTP effluent, stormwater output, affluent confluences and a marsh area). Samples were collected on the 24 September 2007 on the Prédecelle River and on the 25 September on the Orge River downstream the Remarde confluence (figure 1). As we wanted to characterize the longitudinal gradient of contamination, we choose to sample during dry flow; flow rates were below 0.9 $\mathrm{m}^{3} \cdot \mathrm{s}^{-1}$ for the Orge river. A rain event occurred on the 24 September and allowed to collect a stormwater sample (i.e., mixture of rain water runoff and domestic wastewater from a combined sewer system).

For each sampling site, 1L surface water or WWTP effluent was collected in amber glass bottles with teflon caps, previously washed and rinsed with methanol and ultrapure water. Special care was taken to rinse the bottle at least twice with sampling water before collection. Two samples were collected at each site, one for analytical measurement and one for biological testing.

\section{Figure 1}

\subsection{Chemical analysis of the 5 estrogenic hormones}

We analysed the dissolved fraction of hormones, including the free and the conjugated forms. The analytical methodology is described in details in another paper [27]; the main steps are briefly described below.

\subsubsection{Preparation before extraction}

Aqueous samples were filtered on site, on the same day, through pyrolyzed $\left(450^{\circ} \mathrm{C}, 1 \mathrm{~h}\right)$ glass fiber filter (GF/F, $0.7 \mu \mathrm{m}$ pore size). Then, the samples were submitted to enzymatic hydrolysis by beta glucuronidase aryl sulfatase from Helix pomatia $(1 / 1000-\mathrm{v} / \mathrm{v})$ at $\mathrm{pH} 5.2$ and $52^{\circ} \mathrm{C}$ during $15 \mathrm{~h}$. 
Perdeuterated hormones (E1-D4, 17 $\beta$-E2-D2, 17 $\alpha$-EE2-D4 and E3-D2), used as internal surrogates, were spiked before the extraction step: at a concentration of $125 \mathrm{ng} \cdot \mathrm{L}^{-1}$ in WWTP influents and $50 \mathrm{ng} \cdot \mathrm{L}^{-1}$ in effluents or river waters.

\subsubsection{Extraction and clean-up protocols}

Sample volumes were $100 \mathrm{~mL}$ for influents and $250 \mathrm{~mL}$ for river waters and effluents. Solid phase extractions were performed with an Autotrace workstation (Caliper Life Science) with Oasis HLB cartridges as follows: after washing with $6 \mathrm{~mL}$ of methanol and $6 \mathrm{~mL}$ of ultrapure water, sample was percolated and elution was achieved with $4 \mathrm{~mL}$ of a mixture ethyl acetate / methanol $(70 / 30-v / v)$. The extract was evaporated to dryness and reconstituted in a mixture of $1 \mathrm{~mL}$ of methylene chloride/heptane $(50 / 50, \mathrm{v} / \mathrm{v})$. Then, the extract was purified on Florisil as follows: after percolation of the extract, $5 \mathrm{~mL}$ of a mixture of acetone/heptane (75 / 25 $\mathrm{v} / \mathrm{v}$ ) were used for elution, then evaporation to dryness was performed and the extract was reconstituted in $200 \mu \mathrm{L}$ of a mixture of water/acetonitrile - 60/40 - v/v. Finally, $\beta$-estradiol acetate, used as internal standard, was spiked at $40 \mu \mathrm{g} \cdot \mathrm{L}^{-1}$ just before injection in the chromatographic system.

\subsubsection{Liquid chromatography and tandem mass spectrometry}

Chromatographic analysis were performed on Xbridge Waters C18 endcaped column (150 mm x $2.1 \mathrm{~mm} \times 3.5 \mu \mathrm{m}$ ) and guard column with an Agilent 1110 coupled with an API 4000 with triple quadrupole mass spectrometer (Applied Biosystems-MDS Sciex). The injected volume was $10 \mu \mathrm{L}$. A gradient with LC grade water and acetonitrile (flow rate of $0.2 \mathrm{~mL} \cdot \mathrm{min}^{-}$ ${ }^{1}$ ) was applied for the separation of the 5 hormones: $40 \%$ acetonitrile from 0 to $2 \mathrm{~min}$, up to $80 \%$ acetonitrile at $4.5 \mathrm{~min}$ and until $15 \mathrm{~min}$. The column temperature was set at $35{ }^{\circ} \mathrm{C}$. Ionization was performed with an electrospray source in a negative mode and acquisition was achieved in Multiple Reaction Monitoring (MRM) mode. As recommended in the EU Commission Decision 2002/657/EC [28], the MS-MS conditions included the use of 2 ionization transitions for each compound (except for the perdeuterated surrogates), one for the quantification (QT) and one for the identity confirmation (CT). Final concentrations were calculated using recoveries obtained for the internal perdeuterated surrogates $(17 \alpha-E 2-\mathrm{D} 2$ is corrected by $17 \beta-\mathrm{E} 2-\mathrm{D} 2)$.

\subsubsection{Performances of the analytical method and quality controls}


The performances of the method are presented in details in another paper [27]. The method was validated according to the French standard NF XPT 90-210 [29]. Acceptable linear responses were obtained for all 5 hormones using standard mixtures containing $0.5 \mu \mathrm{g} \cdot \mathrm{L}^{-1}$ to $80 \mu \mathrm{g} \cdot \mathrm{L}^{-1}$ of hormones in vials before injection, which correspond to concentration ranges from 1.0 to $200 \mathrm{ng} \cdot \mathrm{L}^{-1}$ for influents and from 0.4 to $80 \mathrm{ng} \cdot \mathrm{L}^{-1}$ for effluents and river waters. During validation of the method, limit of quantification (LOQ) were estimated from $0.4 \mathrm{ng} \cdot \mathrm{L}^{-1}$ for E1 and $\alpha$-E2 to $1.0 \mathrm{ng} \cdot \mathrm{L}^{-1}$ for EE2 in surface and effluent waters, and from 0.8 for $\alpha-\mathrm{E} 2$ to $3.0 \mathrm{ng} \cdot \mathrm{L}^{-1}$ for EE2 in influent waters. However, LOQ are highly dependant on the sample matrix and on the sensitivity of the instrument, which can vary from day to day. For this study, results were considered higher than the LOQ when (i) the 2 ionization transitions (for the quantification and for the identity confirmation) were confirmed as explained in the EU Commission Decision 2002/657/EC [28] and (ii) the concentration value was within the range of the calibration curve. Within-day recoveries obtained for 5 replicate samples of surface water, WWTP influent and effluent generally ranged from 82 to $115 \%$ with relative standard deviations lower than $22 \%$. Specificity of the method was verified for the 5 estrogenic hormones, which means that matrix effects are not significant (i.e., the use of perdeuterated hormones as internal surrogates appears to be an efficient method to correct for matrix effects).

During the samples analysis, we obtained satisfying quality controls: none of the 5 estrogenic hormones was detected in blank samples; we verified that the instrumental sensitivity did not vary by the use of standard solutions.

\subsection{Biological analysis of estrogenic disrupting effects}

\subsubsection{Materials and chemicals}

17ß-estradiol ( $\beta$-E2) was from Sigma-Aldrich (St-Quentin-Fallavier France). Standard solutions were made in dimethylsulfoxyde (DMSO, HPLC grade, Sigma-Aldrich). For sample preparation, glass fiber filters $(1 \mu \mathrm{M})$ were from Whatman and Oasis HLB-500 mg cartridges were purchased from Waters (Guyancourt, France). Methanol HPLC grade, acetone Normapur ${ }^{\circledR}$ and hexane Pestinorm ${ }^{\circledR}$ were from VWR (Strasbourg, France). The material for cell culture was supplied by Life Technologies (Cergy-Pontoise, France). The luciferase reporter gene assay kit was supplied by Roche Applied Science (Meylan, France) and a Centro LB 960 microplates luminometer (Berthold, Thoiry, France) was used for luminescence measures. 


\subsubsection{Liquid samples preparation}

Sample preparation procedures were similar to that of chemical analysis, but special care was taken to avoid contamination from extraction material that could lead to false positive results. Sample preparation was proceeded within 24 hours after collection. Filtered liquid phase was extracted on Oasis HLB cartridges previously washed with $10 \mathrm{~mL}$ methanol and $10 \mathrm{~mL}$ purified water. Then, $1 \mathrm{~L}$ of water sample was passed through the cartridge at a flow rate of 6 $\mathrm{mL} \cdot \mathrm{min}^{-1}$. After drying the cartridge for $5 \mathrm{~min}$ under vacuum aspiration, elution was carried out using $10 \mathrm{~mL}$ of methanol at a flow rate of $1 \mathrm{~mL} \cdot \mathrm{min}^{-1}$. Then, the extract was evaporated to dryness under nitrogen at $40^{\circ} \mathrm{C}$ and dissolved in $350 \mu \mathrm{L}$ DMSO; it was then stored at $-20^{\circ} \mathrm{C}$ before analysis. Just before biological testing, the extract has to be diluted 1000-fold to avoid cellular toxicity.

\subsubsection{Biological tests}

One bioluminescent cellular model was used to test the estrogen receptors agonist potential of the samples extracts: the MELN cells were kindly provided by Dr P. Balaguer, INSERM U 439, Montpellier, France. The cells were seeded into 96-wells white opaque culture plates at a density of $2.10^{4}$ cells per well and left to develop 24 hours before use. DMSO extracts of sample or calibration standards of $\beta$-E2 $\left(10^{-13}\right.$ to $\left.10^{-8} \mathrm{~mol} \cdot \mathrm{L}^{-1}\right)$ were left $16 \mathrm{~h}$ for incubation at $37^{\circ} \mathrm{C}$. Then the cells were washed twice with PBS buffer and luciferase activity was measured on lysed cells. Each analysis was repeated 5 times using 5 replicate culture wells. The mean of the 5 luminescence activities was used for calculation and results were expressed as relative luminescence unit (RLU) that corresponds to the mean luminescence value related to the one of DMSO control.

In parallel to the MELN cells, cellular viability was verified using MTT test as described by Mosmann, T. [30].

\subsubsection{Performances of the biological tests}

Limit of detection (LOD), estimated as the concentration of hormone leading to a luciferase activity significantly different $(\mathrm{p}=0.05)$ from DMSO control, was $0.1 \mathrm{pM}\left(0.03 \mathrm{ng} \cdot \mathrm{L}^{-1}\right.$ of $\beta$ E2). Repeatability was around $12 \%$ for each test $(n=5)$. Sigmoïdal dose-response curves were estimated from calibration standards allowing LOQ in a range from $10^{-12} \mathrm{M}$ to $10^{-9} \mathrm{M}(0.3$ to $272 \mathrm{ng} \cdot \mathrm{L}^{-1}$ of $\left.\beta-\mathrm{E} 2\right)$. 
In order to determine the relative biological activity of the chemically analysed estrogens, dose-response curves were drawn using calibration standards of hormone for each compound leading to EC50 values of $193.3 \mathrm{pM}\left(52.3 \mathrm{ng} \cdot \mathrm{L}^{-1}\right)$ for $\mathrm{E} 1,6.3 \mathrm{pM}\left(1.69 \mathrm{ng} \cdot \mathrm{L}^{-1}\right)$ for $\beta$-E2, 69.4 pM $\left(20.0 \mathrm{ng} \cdot \mathrm{L}^{-1}\right)$ for $\mathrm{E} 3$ and $3.9 \mathrm{pM}\left(1.16 \mathrm{ng} \cdot \mathrm{L}^{-1}\right)$ for EE2. The relative potencies to $\beta-\mathrm{E} 2$ (EC50 ratio), estimated from 3 repeated curves in a same run, were $0.04 \pm 0.01,0.11 \pm 0.04$ and $1.79 \pm 0.45$ for E1, E3 and EE2, respectively.

\section{Results and discussion}

\subsection{Chemical analysis}

Concentrations of the 5 estrogenic hormones are reported in Figure 2. E1 was quantified in all samples: from $0.1 \mathrm{ng} \cdot \mathrm{L}^{-1}$ downstream Limours (station 2) to $15.7 \mathrm{ng} \cdot \mathrm{L}^{-1}$ in Briis WWTP effluents (station 3). A relatively high concentration $\left(13.7 \mathrm{ng} \cdot \mathrm{L}^{-1}\right)$ was also measured in the urban storm runoff (upstream Limours, station 1). $\beta$-E2 was also quantified in all samples, but at a lower level: from $2.3 \mathrm{ng} \cdot \mathrm{L}^{-1}$ in the urban storm runoff (upstream Limours, station 1) to 0.1 $\mathrm{ng} \cdot \mathrm{L}^{-1}$ downstream St Germain les Arpajons (station 6). $\alpha$-E2 was never detected. EE2 was only quantified in Briis WWTP effluent (0.2 $\mathrm{ng} \cdot \mathrm{L}^{-1}$, station 3); E3 was measured in Briis WWTP effluent (12.1 ng. $\mathrm{L}^{-1}$, station 3) and downstream Briis effluent (4.9 $\mathrm{ng} \cdot \mathrm{L}^{-1}$, station 4). When compared with the levels of other hormones, the higher concentrations of E1 can be partly explained by the fact that it is a degradation product of $\beta$-E2 and EE2. The decreasing concentrations of E1 and $\beta$-E2 from the urban storm runoff upstream Limours to downstream Limours (stations 1 and 2) can be explained by the dilution in the river flow, degradation and adsorption on river sediment. If we consider the concentration of E1 or the sum of concentration of the five hormones, we observed a strong decreasing gradient all along the Prédecelle river, from the WWTP Briis effluent input (station 3), identified as a source of contamination, to the connection with the Orge river at St Germain les Arpajons (station 6).

As mentioned in Figure 1, river flows measured on the $25^{\text {th }}$ of September were equal to 0.65 $\mathrm{m}^{3} \cdot \mathrm{s}^{-1}$ for the Yvette river at Villebon (i.e., $10 \mathrm{~km}$ upstream the connection with the Orge river), $1.16 \mathrm{~m}^{3} \cdot \mathrm{s}^{-1}$ for the Orge river upstream the connection with the Yvette river and 1.94 $\mathrm{m}^{3} \cdot \mathrm{s}^{-1}$ for the Orge river at Morsang, downstream the connection with the Yvette river. We can estimate the mean daily flow of the sum of the 5 hormones from the measured concentrations (i.e., sum of the 5 hormones concentrations $\mathrm{x}$ river flow). This estimated hormones flow in the Orge river at Morsang downstream the Yvette river (station 9, $4.07 \mu \mathrm{g} \cdot \mathrm{s}^{-}$ ${ }^{1}$ ) is similar to the one in the Yvette river (station $8,1.76 \mu \mathrm{g} \cdot \mathrm{s}^{-1}$ ) plus the one in the Orge river 
upstream the Yvette river (station 7, $2.00 \mu \mathrm{g} \cdot \mathrm{s}^{-1}$ ). These results allow to validate our concentration measurements.

For information, from [31], the mean annual river flow is $1.33 \mathrm{~m}^{3} \cdot \mathrm{s}^{-1}$ for the Yvette river at Villebon (evaluated over a period from 1968 to 2008), $2.23 \mathrm{~m}^{3} \cdot \mathrm{s}^{-1}$ for the Orge river upstream the connection with the Yvette river (evaluated over a period from 1982 to 2008) and 3.89 $\mathrm{m}^{3} \cdot \mathrm{s}^{-1}$ for the Orge river at Morsang, downstream the connection with the Yvette river (evaluated over a period from 1967 to 2008).

\section{Figure 2.}

\subsection{Biological analysis}

Estrogenic potential, reported as RLU in Figure 3, was observed for all samples. A high RLU value of 22.6 was observed in WWTP effluent that decreased downstream as a function of the distance from the river input. In the same way, a RLU value of 14.1 was observed in the Yvette river, with a constant decrease observed after the confluence with the Orge river. Meanwhile, estrogenic activities were generally low and quantification was only possible for five samples over 10: $2.8 \mathrm{ng} \cdot \mathrm{L}^{-1}$ EEQ was quantified in the WWTP effluent and values near 1 $\mathrm{ng} \cdot \mathrm{L}^{-1}$ EEQ were quantified for the four river samples (Figure 4). These values are similar to the ones reported in surface waters of the Seine river in our previous study [5].

\section{Figure 3.}

\subsection{Chemical vs biological analysis}

The comparison of chemical analysis and relative luminescence units (RLU) in Figures 2 and 3, respectively, showed similar profiles, especially for the decreasing concentrations downstream the WWTP effluent input and for the mixing of Yvette and Orge rivers beyond the confluence.

The chemical EEQ values were calculated from E1, $\beta$-E2, E3 and EE2 concentrations weighted by a ponderation factor obtained from relative estrogenic potential on MELN cells (i.e., a ponderation factor equal to 1.79 for EE2, 1.00 for $\beta$-E2, 0.11 for E3, and 0.04 for E1). In Table 2, these chemical EEQ values were compared to the RLU values obtained from the MELN test: a good correlation was confirmed with a Spearman Rank test coefficient of 0.87 $(\mathrm{p}<1 \%)$.

\section{Table 2.}


The biological EEQ values were determined for the five samples with RLU values above the LOQ. From Figure 4, we observe that the chemical EEQ is higher than the biological EEQ in the urban storm runoff. Chemical and biological EEQ are comparable for WWTP effluent and downstream WWTP, in which estrogenic hormones seem to be responsible for more than $90 \%$ of the biological effect. For five samples, chemical EEQ can be quantified contrary to biological ones (i.e., in the Prédecelle river downstream Limours and in the 4 sites of the Orge river). For two river samples - in the Prédecelle river downstream Vaugrigneuse pond and in the Yvette river at Epinay - the chemical EEQ are lower than the biological EEQ. For these two last samples, a contribution of other estrogenic disruptors has to be taken into account; this may explain the lower contribution (about 50\%) of estrogenic hormones to biological effect. The result obtained in the urban storm runoff upstream Limours is clearly different from the others with a chemical EEQ two fold higher than the biological one. In our previous study carried out near WWTP in the river Seine [5], chemical EEQ values varied between 4.1 and $7.3 \mathrm{ng} \cdot \mathrm{L}^{-1}$ for surface water, whereas biological EEQ remained around $1 \mathrm{ng} \cdot \mathrm{L}^{-1}$ and the contribution of EE2 was estimated between 35 and $48 \%$. In the present study, EE2 was not quantified in surface water. The low biological activity observed upstream Limours could be partly explained by an inhibition effect due to organic pollutants mixture present in the sample. This was clearly observed by Salste et al. [18], who studied some chromatographic fractions from WWTP effluent samples and showed the inhibition on $\beta$-E2 activity measured with YES tests. The compounds responsible for this inhibition effect were supposed to interfere with the estrogen receptor.

\section{Figure 4.}

\section{Conclusion}

Combining chemical and biological analysis of estrogenic disruptors allowed to confirm a tendency of decreasing contamination along the studied rivers of Prédecelle, Yvette and Orge, downstream a WWTP effluent and an urban storm runoff. This study showed that the biological responses using the MELN test closely followed the chemical ones. The total (including the conjugated fraction) dissolved concentrations of the 5 hormones seem to be a good tracer of urban source of contamination of estrogenic disruptors in wastewaters and surface waters. Chemical analysis had the following advantages: (i) to reach lower LOQ than MELN tests, this was verified on river samples collected at 5 sites; (ii) to be specific (i.e., not affected by matrix interferents) thanks to the use of perdeuterated hormones; (iii) to be 
selective (i.e., to quantify individually each of the 5 estrogenic hormones).Bioassays, such as MELN tests, have the advantage to measure the estrogenic effect related to hormones and also to other estrogenic disruptors present in the samples. Thus, they can be better adapted to screen estrogenic disruption in aquatic environments exposed to urban and industrial sources of contamination. However, the possible inhibition effect from mixture of pollutants should be taken into account by performing chromatographic fractionation of samples and biological testing of the isolated fractions individually. In conclusion, analytical quantification of estrogens appears to be a simple way to trace estrogenic disruption in surface waters of urban areas as these hormones are the main responsible of effects.

\section{Acknowledgments}

This study was supported by the Piren Seine program (CNRS) and a Ph. D. grant from Cemagref for V. Gabet. We thank Ph. Bados (Cemagref) for help for sample analysis, M. Bimbot and V. Huteau (Faculté de Pharmacie - Laboratoire Santé Publique Environnement) for technical support for biological tests, Mr. Deschamps (from "Syndicat intercommunal d'assainissement des communes de Limours") for access to river sites, Mr Hollander (from "Lyonnaise des eaux") for access to the WWTP. 


\section{Figures}
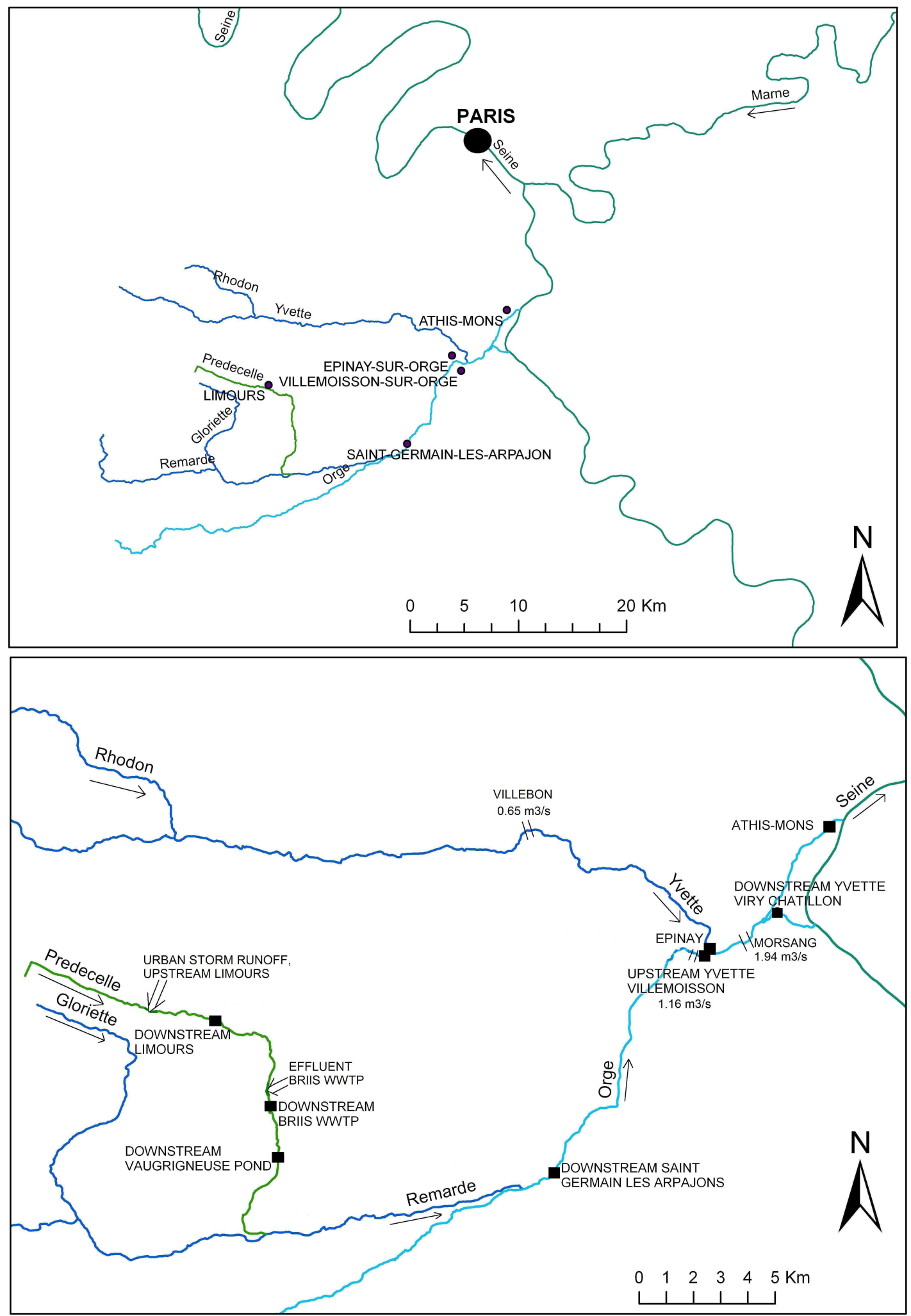

Figure 1: Sampling sites on the Orge catchment, Paris area $(\boldsymbol{\square}$ and $\Rightarrow)$ and sites for river flows measurements (=). 


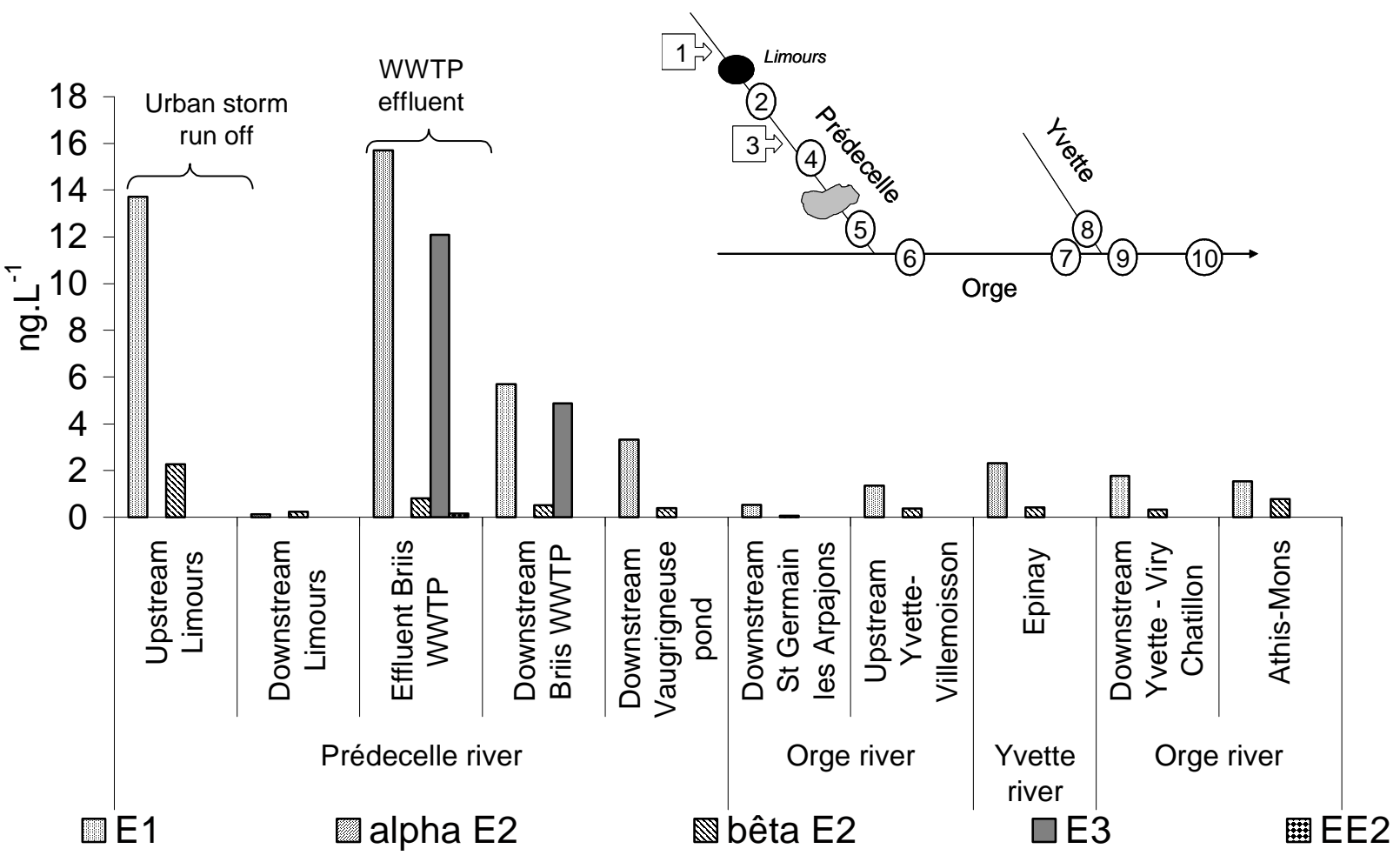

Figure 2: Concentration (ng $\mathrm{L}^{-1}$ ) of the 5 estrogenic hormones in the dissolved phase of surface waters, storm runoff and WWTP effluent from selected sites on the Orge catchment.

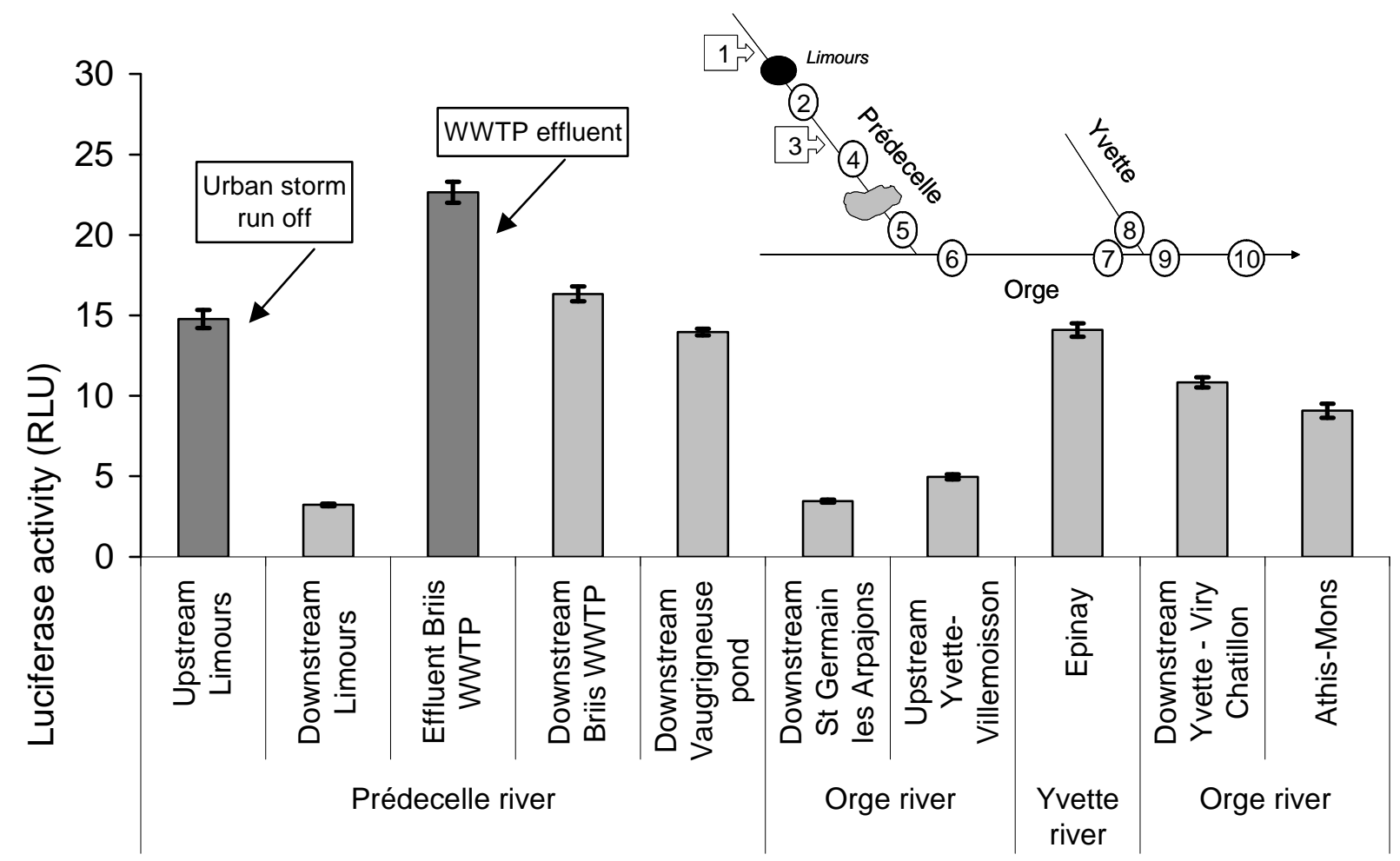

Figure 3: Estrogenic disruption measured by MELN tests (expressed in relative luminescence units, RLU) in the dissolved phase of surface waters, storm runoff and WWTP effluent from selected sites on the Orge catchment. 


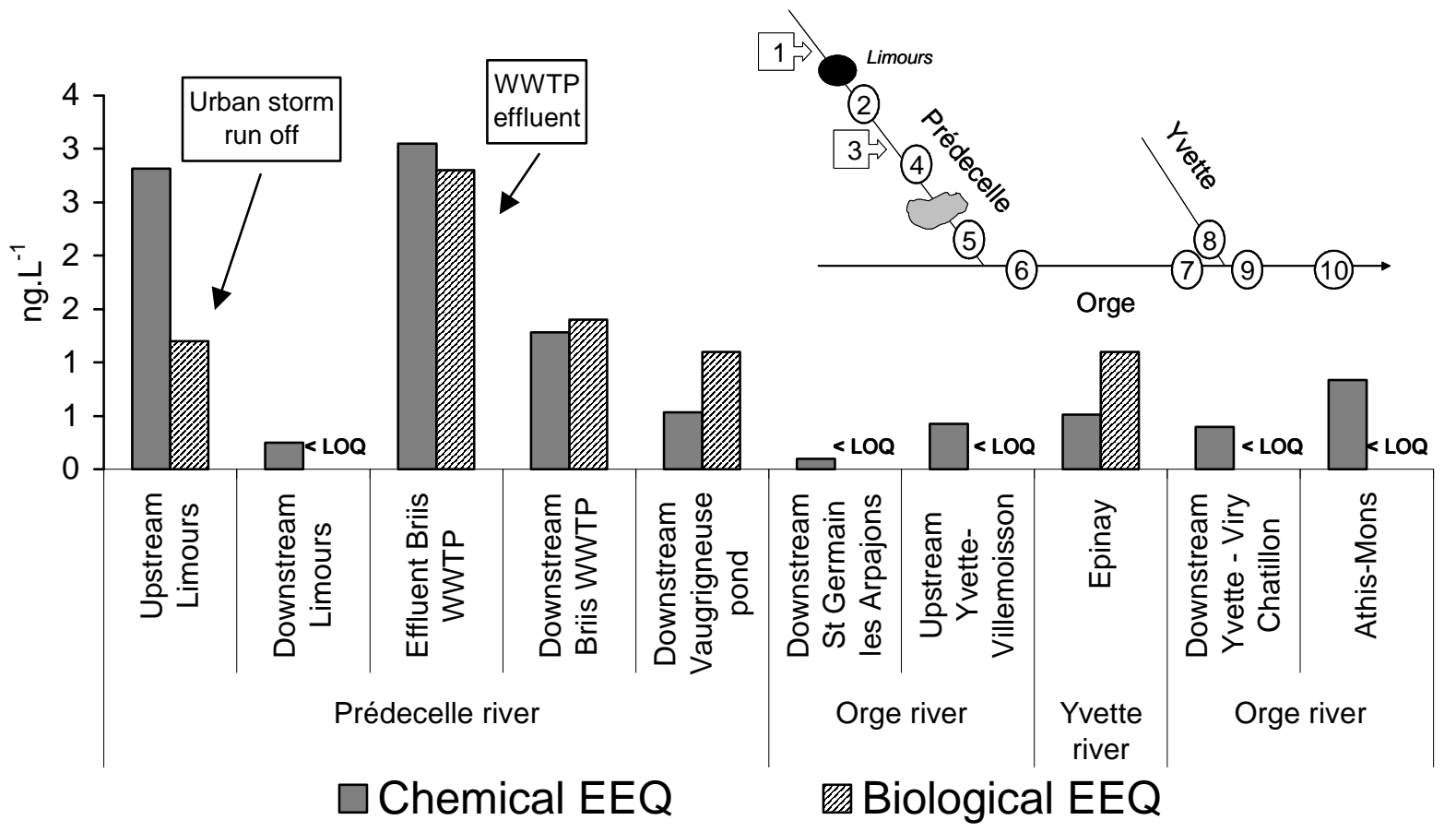

Figure 4: Comparison of equivalent estrogenic quantity (EEQ) obtained either from chemical or biological measurements. Biological EEQ was not quantified for samples with RLU value under LOQ. 


\section{Tables}

Table 1: Mean, minimum, maximum concentrations and removals (with relative standard deviation) for estrogenic hormones in wastewater treatment plants with activated sludge processes (from [4]).

\begin{tabular}{|c|c|c|c|c|c|c|c|c|c|c|c|}
\hline \multirow[t]{2}{*}{ Hormones } & \multicolumn{4}{|c|}{$\begin{array}{l}\text { Influent concentration } \\
\left(\text { ng. } L^{-1}\right)\end{array}$} & \multicolumn{4}{|c|}{$\begin{array}{l}\text { Effluent concentration } \\
\left(\text { ng. } L^{-1}\right)\end{array}$} & \multicolumn{3}{|c|}{$\begin{array}{l}\text { Removal } \\
(\%)\end{array}$} \\
\hline & $\min$ & $\max$ & mean & $\mathbf{n}$ & min & $\max$ & mean & $\mathbf{n}$ & $\mathbf{R}$ & RSD & $\mathbf{n}$ \\
\hline E1 & 2.4 & 670 & 67 & 109 & 0.6 & 95 & 21 & 79 & 74 & 39 & 59 \\
\hline$\alpha-E 2$ & 1.5 & 17 & 7.4 & 36 & 0.1 & 3 & 0.8 & 9 & 79 & 22 & 6 \\
\hline$\beta-\mathrm{E} 2$ & 2.5 & 125 & 22 & 108 & 0.3 & 30 & 2.8 & 63 & 88 & 13 & 52 \\
\hline EE2 & 0.4 & 70 & 4.2 & 70 & 0.2 & 5 & 0.9 & 33 & 68 & 33 & 46 \\
\hline E3 & 15 & 660 & 115 & 36 & 0.4 & 275 & 13 & 33 & 92 & 20 & 36 \\
\hline
\end{tabular}

n: number of individual data

Table 2: Comparison study between relative luminescence units (RLU) values and chemical equivalent estrogenic quantity (EEQ).

\begin{tabular}{lcc}
\hline Sample sites & RLU & $\begin{array}{c}\text { Chemical EEQ } \\
\left(\mathbf{n g} \cdot \mathbf{L}^{-1}\right)\end{array}$ \\
\hline Urban storm runoff, upstream Limours & 14.77 & 2.82 \\
Prédecelle river, downstream limours & 3.22 & 0.25 \\
Effluents Briis WWTP & 22.66 & 3.13 \\
Prédecelle river, downstream Briis WWTP & 16.34 & 1.28 \\
Prédecelle river, downstream Vaugrigneuse pond & 13.97 & 0.53 \\
Orge river, downstream St Germain les Arpajons & 3.46 & 0.10 \\
Orge river, upstream Yvette-Villemoisson & 4.97 & 0.43 \\
Yvette river, Epinay & 14.09 & 0.51 \\
Orge river, downstream Yvette Viry-Chatillon & 10.84 & 0.40 \\
Orge river, Athis-Mons & 9.07 & 0.84 \\
\hline
\end{tabular}




\section{References}

[1] M.L. Richardson, J.M. Bowron, J. of Pharm. and Pharmacol. 37 (1985) 1.

[2] B. Halling-Sorensen, S.N. Nielsen, P.F. Lanzky, F. Ingerslev, H.C.H. Lutzhoft, S.E. Jorgensen, Chemosphere 36 (1998) 357.

[3] M.Y. Gross-Sorokin, S.D. Roast, G.C. Brighty, Environ. Health Perspect. 114 (2006) 147.

[4] C. Miège, J.M. Choubert, L. Ribeiro, M. Eusèbe, M. Coquery, Environ. Poll., in press.

[5] M. Cargouet, D. Perdiz, A. Mouatassim Souali, S. Tamisier-Karolak, Y. Levy, Sci. Total Environ. 324 (2004) 55.

[6] P. Labadie, H. Budzinski, Environ. Sci. Technol. 39 (2005) 5113.

[7] S. Zuehlke, U. Duennbier, T. Heberer, J. Sep. Sci. 28 (2005) 52.

[8] T.A. Ternes, Trends Anal. Chem. 20 (2001) 419.

[9] H.M. Kuch, K. Ballschmiter, Environ. Sci. Technol. 35 (2001) 3201.

[10] I.C. Beck, R. Bruhn, J. Gandrass, W. Ruck, J. Chromatogr. A 1090 (2005) 98.

[11] A. Lagana, A. Bacaloni, I. De Leva, A. Faberi, G. Fago, A. Marino, Anal. Chim. Acta 501 (2004) 79.

[12] E. Zuccato, S. Castiglioni, R. Fanelli, J. .Hazard. Mater. 122 (2005) 205.

[13] G.R. Boyd, H. Reemtsma, D.A. Grimm, S. Mitra, Sci. Total Environ. 311 (2003) 135.

[14] M. Farre, R. Brix, M. Kuster, F. Rubio, Y Goda, M.L. De Alda, D. Barcelo, Anal. Bioanal. Chem. 285 (2006) 1001.

[15] G. Morteani, P. Moller, A. Fuganti, T. Paces, Environ. Geochem. Hlth 28 (2006) 257.

[16] P. Labadie, E. M. Hill. J. Chromatogr. A 1141 (2007) 174

[17] J. Nelson, F. Bishay, A. van Roodselaar, M. Ikonomou, F.C. Law, Sci. Total Environ. 374 (2007) 80.

[18] L. Salste, P. Leskinen, M. Virta, L. Kronberg, Sci. Total Environ. 348 (2007) 343.

[19] B.V. Rutishauser, M. Pesonen, B.I. Escher, G.E. Ackermann, H.R. Aerni, M.J. Suter, R.I. Eggen, Environ. Toxicol. Chem. 23/4 (2004) 857.

[20] I.C. Beck, R. Bruhn, J. Gandrass, Chemosphere 63 (2006) 1870.

[21] W. Korner, U. Bolz, W. Sussmuth, G. Hiller, W. Schuller, V. Hanf, H. Hagenmaier, Chemosphere 40 (2000) 1131.

[22] A.J. Murk, J. Legler, M.M. van Lipzig, J.H. Meerman, A.C. Belfroid, A. Spenkelink, B. van der Burg, G.B. Rijs, D. Vethaak, Environ. Toxicol. Chem. 21/1 (2002) 16.

[23] A. Pillon, A.M. Boussioux, A. Escande, S. Ait-Aissa, E. Gomez, H. Fenet, M. Ruff, D. Moras, F. Vignon, M.J. Duchesne, C. Casellas, J.C. Nicolas, P. Balaguer, Environ. Health Perspect. 113 (2005) 278.

[24] E. Sonneveld, J.A. Riteco, H.J. Jansen, B. Pieterse, A. Brouwer, W.G. Schoonen, B. van der Burg, Toxicol. Sci. 89 (2006) 173.

[25] P. Berckmans, H. Leppens, C. Vangenechten, H. Witters, Toxicol. In Vitro 21/7 (2007) 1262.

[26] S. Bremer, oral communication in ECVAM (European Center for the Validation of Alternative Methods) meeting on the Refinements of in vivo Tests assessing the reproductive/developmental hazards of Chemicals, 7 sept 2006, Ispra, Italy.

[27] C. Miège, P. Bados, C. Brosse, M. Coquery, Trends Anal. Chem, accepted

[28] COMMISSION DECISION of 12 August 2002 implementing Council Directive 96/23/EC concerning the performance of analytical methods and the interpretation of results (2002/657/EC), 29p

[29] AFNOR, Norme NF XPT 90-210, Protocole d'évaluation d'une méthode alternative d'analyse physico-chimique par rapport à une méthode de référence (1999), 58p

[30] T. Mosmann, Journal of Immunological Methods 65/1-2 (1983) 55.

[31] Hydrological database, http://www.hydro.eaufrance.fr/index.php 